\title{
Educating the sense of rhythm in primary education students
}

\author{
Silvia GRĂDINARU ${ }^{1}$
}

\begin{abstract}
Background: Rhythm as a core element of complex coordination is the key to efficient moulding of motor skills specific to sports activities in curricula. Practicing physical exercise in a varied rhythm and tempo in primary school students moulds the skill of achieving correct movement basics (direction, span, coordination, and expressivity). The use of music in sports classes improves kinetics and vestibular sensitivity. The sense of rhythm and tempo are imperative criteria in vocational schools. Purpose: This paper aims to describe a pattern of means selected to develop the sense of rhythm and to allow movements in different sports branches with increased efficiency. Methods: The test battery was applied on a sample of 15 students from the 4th grade of the "Ion Vidu" National Arts College in Timisoara, Romania, aged 910 years, over an entire school year, using different rhythms and tempos during sports classes, which were later used in gymnastics, athletic events, and basketball. Results: Data recorded after the application tests, processed and interpreted confirms the proposed assumption and validates the motor contents used. Conclusions: Sense of rhythm is a component of coordinative capacity that is required to be educated from an early age. Rhythmic movements are easier to automate saving energy and motivating students to an active and conscious participation.
\end{abstract}

Key words: rhythmicity, tempo, vocational school, coordinating ability

\section{Rezumat}

Introducere: Ritmul ca element central al coordonării complexe este cheia în realizarea cu eficacitate a deprinderilor motrice specific disciplinelor sportive cuprinse în planul de învățământ. Practicarea exercițiilor fizice în ritm și tempou variat, la copii din ciclul primar, creează deprinderea de a executa corect bazele generale ale mișcării (direcție, amplitudine, coordonare, expresivitate) iar prin folosirea muzicii în lecție se perfecționează sensibilitatea kinestezică și vestibulară. Simțul ritmului și tempoul sunt criterii imperative necesare pentru a fi admise în cadrul școlii cu profil vocațional. Scop: Lucrarea urmărește elaborarea unui model de mijloace selecționate pentru dezvoltarea simțului ritmului și posibilitatea de a efectua mișcările propuse din ramurile de sport abordate cu eficiență sporită. Metode: Bateria de teste a fost aplicată pe un lot de 15 eleve din clasele a IV-a de la Colegiul Național de Arte Ion Vidu Timișoara, având vârsta de 9-10 ani, pe parcursul unui an școlar, în lecțiile de educație fizică folosind exerciții în tempouri și ritmuri diferite, aplicate în gimnastică, atletism și baschet. Rezultate: Datele înregistrate în urma aplicării testelor, prelucrate și interpretate confirmă ipoteza propusă și validează conținutul motric utilizat.. Concluzii:Simțul ritmic este o componentă a capacității coordinative care se cere a fi educat la vârste fragede. Mișcările ritmice se automatizează mai ușor economisind energie și motivând elevii într-o participare activă și conștientă.

Cuvinte cheie: ritmicitate, tempou, școală vocațională, capacitate coordinativă

${ }^{1}$ Assistant professor, PhD, Physical Education and Sports Faculty, West University of Timisoara, email:gradinarusilvi@gmail.com 


\section{Introduction}

Rhythm as a core element of complex coordination is the key to efficiently acquiring motor skills specific to sports activities in curricula.

Moving in a varied rhythm and tempo is closely related to a feeling of freedom, of power, of content for overcoming difficulties in a world that is superior to humankind.

Therefore, practicing physical training in primary education allows children to increase their physical training and their motor skills.

Practicing physical exercise in a varied rhythm and tempo in primary school students moulds the skill of achieving correct movement basics (direction, span, coordination and expressivity). Furthermore, practicing physical exercises moulds proper, beautiful posture and using music in sports classes improves kinetics and vestibular sensitivity $[1,2]$.

Nowadays, in physical training classes are used a varied range of basic gymnastics and semiacrobatic elements. They aim to involve the entire body in movement while working in different positions, axes, and planes.

Rhythm and tempo, the two basic elements of musical expressivity, have contributed to exceptional performances by great ballerinas and choreographers in time.

Due to movement rhythm, students can express the character, genus and style of a composition, point out the personality of the creator of a piece, and express their own personality $[3,4]$.

On the other hand, we can say that rhythm dominates not only music and other arts, but the entire universe as well, being inseparable from matter and life and becoming a must in motor activities, mainly in physical training ones [6].

The paper aims to highlight the close relationship between physical education lessons, and lessons where the sense of rhythm and tempo are imperative criteria needed by students to be admitted and to form in vocational schools.

The selection of future students of a vocational school is done through different rhythm and tempo exercises.

In order to contribute to the moulding of the sense of rhythm during physical training classes in primary school, the children being tested need to have acquired almost perfectly the performance technique of the systems in different rhythms and tempos, reaching the peak of qualities and motor skills necessary in all sports branches. The paper is based on the capacity of transmission an emotional states through movement to assist in the understanding of beauty and expressiveness in accordance with rhythm and tempo.

The paper aims to develop proper, creative imagination during physical training classes. It contributes to the moulding of valuable musical culture and it ensures at the same time the possibility of understanding the contents of music and its transmission through movement. Therefore, our goal was to see if the selected means and used over an entire school year could lead to the development of the sense of rhythm and to the possibility of practicing the movements of different sports branches in high efficiency physical training classes.

\section{Material and Method}

The research was carried out during the school year 2013-2014, within the physical training classes of the "Ion Vidu" National Art College from Timisoara. We used the existing material equipment: in summer - sports grounds of the high school, in winter - the great hall of the high school.

The test battery was applied on a sample of 15 students (girls) from the $4^{\text {th }}$ grade at the age of 9-10 years.

In each test, we used a number of classes divided per different periods.

The research relied on a specialty bibliographical study regarding the coordination, rhythm, different rhythm and tempo exercises - all applied in gymnastics, athletic events, and basketball.

We used three types of methods:

1. General methods:

- Historical method;

- Modelling method;

- Heuristic method;

2. Investigation methods, procedures and techniques:

- Observation;

- Pedagogical experiment;

- Bibliographic method;

- Audio-video method;

- Testing; 
3. Analysis and interpretation methods: graphic and comparative analysis methods.

The test battery used in the experiment consisted in the following:

- Selective influence of the motor system using the rhythms 2/4, 3/4 and 4/4;

-Waltz step performance test using the rhythm 3/4;

- Proper stepping through rods test;

- Three-step succession through rods test per time unit;

- Basket throwing from two-step dribbling over a stick test $[5,7]$.

\section{Results}

For the first test, we used the 2/4 tempo since it is the most alert and significant taking into account children's age. From the initial testing to the final one we worked 8 hours for one month.

We observed that at the initial testing (in the stage of selective influence on the motor apparatus 10 minutes), 6 students worked $100 \%$ in the given rhythm, 4 were completely counter rhythm, and 5 students worked $50 \%$ in the given rhythm and tempo.

After one month of working for 8 hours, in the final testing, we could see that 11 students worked $100 \%$ in the given rhythm, 4 worked $80 \%$ in the given rhythm, and only one student worked only $50 \%$ in the given rhythm.

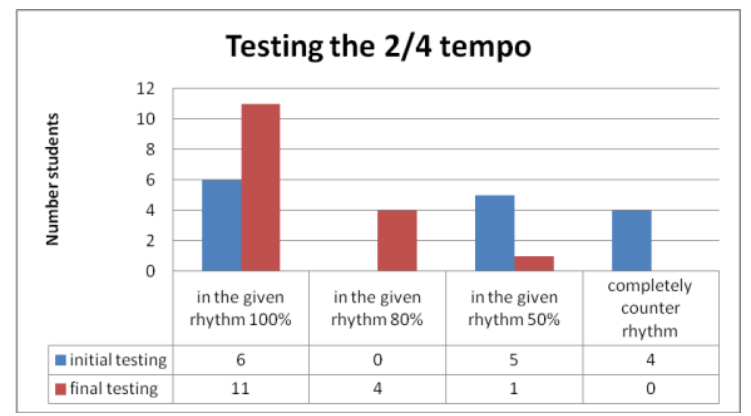

Figure 1. Testing the $2 / 4$ tempo

The results obtained at the waltz step in a rhythm of 3/4 (7-10 minutes) are presented in Figure 2. At the initial testing, 7 students performed the step very well $(80 \%$ of the rhythm); 5 students performed very well during the first 2 minutes and then lost the rhythm and worked in counter rhythm; and 3 students performed 50\% correctly. Upon final testing, we could see that 10 students performed the waltz step $100 \%$ and five students performed it $80 \%$ correctly.

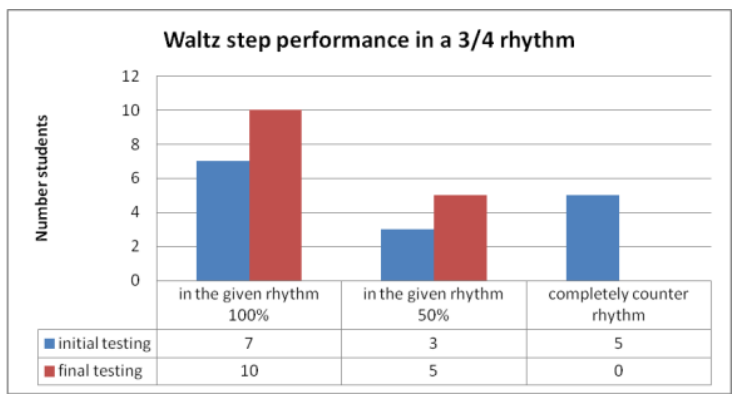

Figure 2. Waltz step performance in a 3/4 rhythm

We also, assessed the performance of stepping through rods and monitored the quality of this performance, the rhythmical, correct succession of the steps. Upon initial testing, 11 students missed $30 \%$ of the three steps, while four students performed the exercise $100 \%$. Upon final testing, 11 students performed only $50 \%$ of the exercise properly, while four students performed the exercise $100 \%$.

The final testing showed progress during the entire year. It showed that some children have a higher ability of perceiving movements and perform correctly from the very beginning. Taking into account the age features, we can say that they understood the importance of performing properly in a very short period (Figure 3).

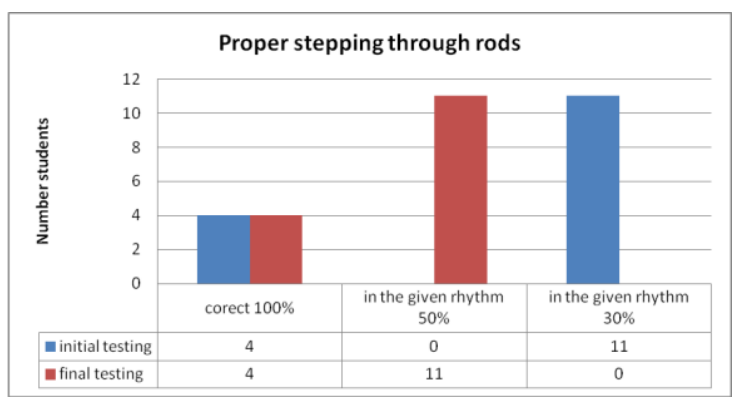

Figure 3. Proper stepping through rods

Furthermore, we monitored the performance of three-step succession through rods per time unit (seconds). Using the same sample to show the performance speed of these steps over $20 \mathrm{~m}$, we could see that from the 11 students, 6 students performed in 5.0-5.10 seconds, 8 students performed in 6.0-6.30 seconds, and 1 student, with special features, performed in 4.09 seconds. Upon final testing, we could see that all students improved the performance speed (between 2-30 
hundreds of second) (Figure 4). In this test, we took into account the fact that all students perform the three steps very well.

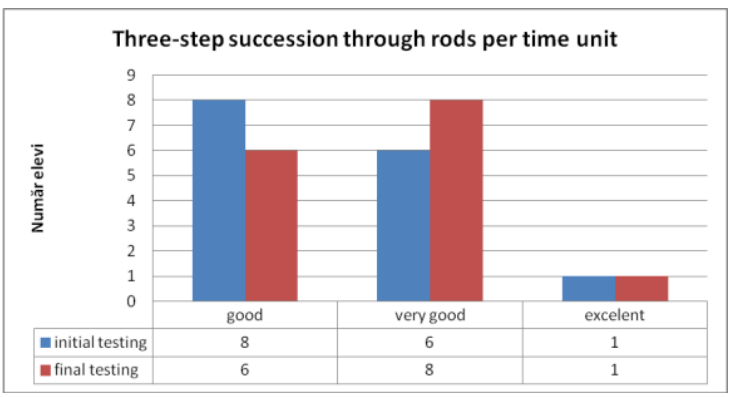

Figure 4. Three-step succession through rods per time unit

We tested the basket throwing from two-step dribbling over a rod, stick or rope, etc. Upon initial testing, from the 15 students, seven students $(47 \%)$ performed the proper step succession while the rest of eight students (53\%) also made mistakes or did not perform well at all. At the final testing, the same seven students performed $100 \%$ properly, while the rest of eight students improved their performance up to $75 \%$. The testing covered 8 hours over an entire semester. Acquiring the rhythm is a general feature of movement in which the steps can be performed easier and with better coordination.

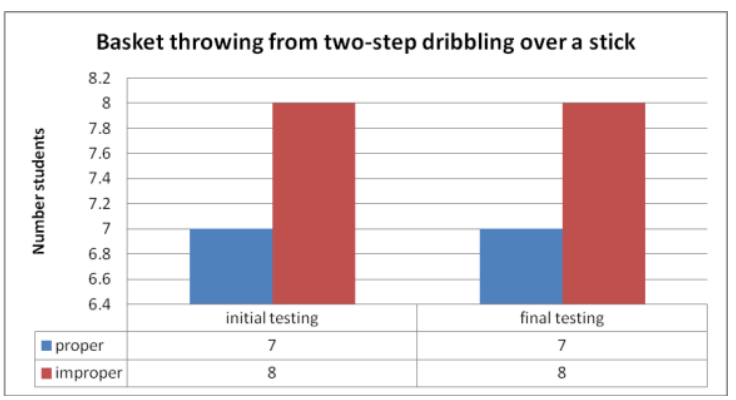

Figure 5. Basket throwing from two-step dribbling over a stick

\section{Conclusions}

We can say that acquiring rhythm is a general feature of movement that can be performed much easier and with better coordination because:

1. Rhythm makes skill acquisition and motor activities easier;
2. Rhythm is important not only within physical training classes, but in other movement-related activities;

3. Repeated movements almost turn automatic and this rhythmical regularity develops a feeling of pleasure and additional motivation through music;

4. Cheer-leader teams can develop based on musical year, sense of rhythm and movement coordination, all of which are developed in physical training class;

5. Our tests showed that developing a sense of rhythm plays an important role in alternating physical effort and rest periods;

6. Rhythmical movements become automatic easier saving energy and motivating the students to participate actively and consciously;

7. Moulding rhythm in physical training classes in the primary school and not only is necessary because they develop a feeling of relaxation, joy, positive load, and ensure optimum tonus for the other activities involving the students.

\section{Recommendations}

In order to make primary school physical training classes more efficient, we suggest the following:

1. Associating movement and music to reduce fatigue and make children perform any motor activity easier;

2. Introducing such exercises in the class to motivate the students use their imagination within a creative environment.

\section{References}

1. Aftimiciuc 0., Chirazi M. (2012) Fitness.Teorie şi metodică, Ed. Pin, Iași.

2. Dragnea A. (1991) Teoria şi metodica dezvoltării calităţilor motrice, Ed. A.N.E.F.S., Bucureşti.

3. Faur M. (2009) Ritmul şi activităţile ritmice, Ed. Politehnica, Timişoara

4. Gonczi Raicu M., Faur M. (1995) Gimnastica acrobatică în scoală la vârsta 7-12 ani, Ed. Mirton, Timișoara

5. Grădinaru C. (2009) Probleme de instruire în jocul de baschet, Ed. Politehnica, Timişoara

6. Săvescu I. (2007) Educaţia-fizică şi sportivă şcolară: Culegere de exerciţii, Ed. Aius Printed, Craiova

7. Săvescu I. (2008) Proiectarea demersului didactic la educaţie-fizică, Ed. Aius Printed, Craiova 